\title{
Discourse and Practice of REDD+ in Ghana and the Expansion of State Power
}

\author{
Shannon Johnson
}

Citation: Johnson, S. Discourse and Practice of REDD+ in Ghana and the Expansion of State Power. Sustainability 2021, 13, 11358. https:// doi.org/10.3390/su132011358

Academic Editors: Adam P. Hejnowicz and Jessica P. R. Thorn

Received: 23 July 2021

Accepted: 22 September 2021

Published: 14 October 2021

Publisher's Note: MDPI stays neutral with regard to jurisdictional claims in published maps and institutional affiliations.

Copyright: (C) 2021 by the author. Licensee MDPI, Basel, Switzerland. This article is an open access article distributed under the terms and conditions of the Creative Commons Attribution (CC BY) license (https:// creativecommons.org/licenses/by/ $4.0 /)$.
Rights and Resources Initiative, Washington, DC 20009, USA; sjohnson@rightsandresources.org

\begin{abstract}
Green market mechanisms, as part of the architecture of climate finance, have become key components of international environmental frameworks. One of the most widely known mechanisms for climate change mitigation has been the creation of Reducing Emissions from Deforestation and Forest Degradation (REDD+). The purpose of this paper is to trace global discourses and narratives throughout REDD+ official documents and compare them to the implementation on the ground to determine the extent that REDD+ meets its stated objectives in the Ghanaian context. Then, given the gaps in discourse and practice, this paper aims to define the inexplicit consequences, or rather instrumental effects, of REDD+. Discourse analysis of official REDD+ documents and land policies combined with qualitative interviews and focus groups to determine the linkages between discourse and practice of REDD+ and the impacts of these gaps. While critical civic environmentalism, highlighting environmental justice as a core principle, was somewhat incorporated into official discourse from the international to the national level, the depoliticization of the discourse and the apolitical nature of interventions make these justice concerns negligible and create gaps in discourse and practice. These gaps create disjointed, infeasible policies that establish REDD+ as a fad to bring in financial resources that expand state control of forest resources under the veil of social-ecological responsibility. As a result, state power expands into rural areas, allowing for greater control over land and forests at the expense of local communities.
\end{abstract}

Keywords: ecological modernization; civic environmentalism; policy implementation; carbon market; state expansion; discourse analysis; neoliberal environmentalism; Ghana; REDD+

\section{Introduction}

The last twenty years has witnessed an increasing utilization of so-called marketbased and financial approaches (e.g., certification, green bonds, payments for ecosystem services, permits, and trading schemes) within the environmental policy and regulatory landscape to address large-scale environmental grand challenges such as biodiversity loss and climate change [1-4]. The turn towards the use and development of market and financial mechanisms and instruments as ways to reduce or reverse environmental harms is often viewed as a political extension of neoliberalism [5-7]. From this vantage, so-called "neoliberal environmentalism" aims to internalize environmental externalities such that environmental problems are solved through privatization, commercialization, and commodification of natural resources and ecosystems [8], and increased private and public-private partnerships instead of state governance [9].

The burgeoning neoliberal environmental agenda can been seen in the rise of climate and green financing-especially in the wake of the Paris Climate Agreement (2015) and 2030 Agenda for Sustainable Development (2015) — which comprises a whole suite of policy mixes, activities and investment funds, targeted at local to global scales, and built around state and private-sector opportunities for low-carbon transitions, greenhouse gas emissions reductions, infrastructure development and ecosystem protection and restoration [10-13]. A notable example of climate financing, which has been the subject of widespread scholarly attention over the last decade is Reducing Emissions of Deforestation and Forest 
Degradation (REDD+), developed as part of the UN-REDD program under the auspices of the United Nations Framework Convention on Climate Change (UNFCCC). Designed to address the linkage between environmental degradation, greenhouse gas emissions and climate mitigation in so-called developing countries, the REDD+ narrative advances the idea of bringing together a diversity of stakeholders to create "a financial value for the carbon stored in forests by offering incentives for developing countries to reduce emissions from forested lands and invest in low-carbon paths to sustainable development" [14]. However, since the beginning, REDD+ has been highly contested for the way it frames both the issue and the solution for deforestation [15-17].

Crucially, REDD+ policies are not neutral, but instead, are constituted and representative of dominant perspectives and knowledge regimes, and products of competing discourses [18,19]. Official REDD+ discourse, at international, national, and sub-national levels, emerges from competing narratives and power relations shaped to both appease and deliver a consensus compromise for all parties of the UNFCCC Conference of the Parties (COP) [20-22]. This is demonstrated by two distinct narratives. Supporters of REDD+ argue for the merits of green capitalism, particularly that the market is a solution to incorporate environmental externalities while promoting sustainable development [23]. The key "green development" assumptions of REDD+ are that forest carbon can be accurately measured; it will be valued higher than other forest commodities; and it will result in equitable poverty alleviation [24]. In contrast, political ecology critics question the "win-win" narrative of green capitalism, arguing that there are inherent trade-offs to valuing forests for primarily for their carbon. They argue that conservation is inherently linked to political, economic, technical, ecological, and social issues that REDD+ does not address [23].

REDD+ created several programmatic elements to address critical concerns such as social and environmental safeguards to protect local interests and co-benefits to forest conservation, collectively known as the "Cancun Safeguards" [25]. REDD+ safeguarding is acknowledged to be a complex issue [25], which partly explains differences in national-level progress (Jagger et al., 2014). At the same time, REDD+ does often have significant and detrimental impacts on local communities, frequently undermining livelihoods, institutions and raising social and environmental justice concerns [26], through for example restricting local forest practices [27].

In West Africa, there is a growing body of research examining stakeholder participation in REDD+ projects [28], and the impacts of REDD+ on local communities such as smallholder famers [29], justice and governance [30], equity [31], and the politics of design and implementation [32]. Across all these areas, challenges and problems have been identified, with some (e.g., [32]) highlighting the national political framing of REDD+ as being particularly instrumental in determining the effectiveness of implementation.

It is against this backdrop that this paper explores the depoliticization, or the removal of issues from political contention [33], of REDD+ discourse in Ghana, pushing the envelope to further extend the understanding of how the political construction of discourse shapes national REDD+ policy processes and impacts. Specifically, this paper combines a critical political ecology approach with poststructuralist discourse theory to examine (i) key legal and REDD+ policy documents, and (ii) national- and district-level policy actors directly or indirectly involved in REDD+ implementation, to critically assess the relationship between REDD+ discourse and practice.

Importantly, what the case of REDD+ in Ghana shows is that official discourse ignored political and power dimensions and so rendered the intervention a purely technocratic process shaped by bureaucratic "governmentality", in which societies, economies, and government bureaucracies respond in reflexive, straight-forward ways to policies and plans. This "depoliticization" is reflected in official REDD+ discourse, which effectively enables the Ghanaian state to divert responsibility for policies that underly deforestation, maintain decision-making power, and enact contradictory national policies in sustainable forestry. At the same time, financial resources are also directed towards the State for the 
infeasible actualization of the forest carbon commodity, leaving critical concerns unaddressed in practice. As a result, the Ghanaian government reaps financial gains without addressing the primary causes of deforestation under the veil of social inclusion. Social and environmental safeguards, then, legitimize expanding state power in practice. This power is cyclical in nature, which expands with each new, depoliticized fad in forest governance. The instrumental effects, or consequence, of an expanding state without local community rights over resources are ultimately criminalization and continued deforestation and forest degradation.

\section{Methodological Framework and Approach}

\subsection{Theoretical Approaches: Critical Political Ecology and Poststructuralist Discourse}

Critical political ecology is place based and incorporates both discourse analysis and qualitative research. Blaikie and Brookfield define political ecology as combining the concerns of ecology and political economy-including the shifting dialectic between society and land-based resources [34]. Forsyth expands this original definition to "critical" political ecology to include a "politicized understanding of environmental explanation beyond the epistemology offered by the critique of capitalism" ([35], p. 7). Critical political ecology seeks to integrate structural and poststructuralist attention on state and industry, in particular, closely examining how interactions between these actors results in the coconstruction of environmental discourses [35].

Poststructuralist discourse theory acknowledges that discourse is a socially constructed phenomenon. It goes further, however, in arguing that this social construction is not simply about subject and object but also encompasses the fluctuating dialectic relationship between them. It is that fluctuation from which meaning emerges, and thus the theory accounts for possible changes in meanings, advancing that meaning (and meaning making by extension) is never fixed and is always to an extent unstable [36]. When discourse is more repeated, the theory posits, it becomes more sedimented and eventually naturalized [24].

This is particularly relevant for new concepts such as carbon storage, carbon market, and restoration that might be common terms and concepts within international policy but relatively alien at the national and especially local levels. In this way, when applied in the context of REDD+ policy, poststructuralist discourse can help associate a certain type of knowledge (international) with power and legitimacy, while devaluing discourse around comprehensive forest management discourse from local communities.

\subsection{Discourse Analysis}

Discourse analysis seeks to understand the debates, narratives, and storylines surrounding a policy. In the case of forest management, discourse determines the meanings that society constructs around forests, which has multi-faceted meanings that make up a field of discursivity [24]. For discourse analysis, 10 official REDD+ policy documents relevant at both the international and national levels were selected, alongside 8 legal documents relating to ownership of land and timber in the Ghanaian content. The documents were coded for key themes including participation, illegalities, land and timber rights, deforestation driver, results-based funding, carbon payments, and social and environmental safeguards. The discourse analysis links the framing of each programmatic aspect of REDD+ with a distinct global narrative, and these narratives were compared to Ghanaian laws and policies relating to land and forests.

\subsection{Key Informant Interviews and Focus Groups}

To explore how REDD+ policy discourse relates to REDD+ practice at the national and sub-national levels, during February and March 2019, a series of stakeholder interviews were undertaken through a combination of semi-structured interviews $(n=20)$ and focus groups $(n=2)$. A diverse set of stakeholders was identified, spanning policy, practice, academic and public and private sectors, largely drawn from snowball sampling. In total, 
20 individuals were interviewed-four officials from the Forestry Commission's Climate Change Unit (Ghana's REDD+ entity); two from the Forestry Commission's district office at Sefwi Wiawso; nine members of forestry civil society; one professor of natural resources; one forestry development consultant; one USAID senior advisor; and two professionals of partner organizations working on Ghana's REDD+ strategy. The focus groups were among various staff members in the Climate Change Unit and with community members from Sefwi Wiawso.

All interviews were conducted in English and followed best practice guidelines as stipulated and approved by the Ethics committee at Geneva Graduate Institute. Crucially, all participants consented to be interviewed. All interviews were fully anonymized.

\subsection{Relating REDD+ Discourse and Practice}

To compare discourse and practice, we follow Ferguson's goal "to connect observed discourse regularities to non-discursive practices and institutions" [37]. This is based on Foucault's contention that discourse is practice and has real effects [38]. Foucault first theorized the "conceptual apparatus" to describe how problems in society were constructed to justify the need for a solution [38]. Similarly, Ferguson described the "development apparatus" as a conceptual apparatus that creates a problematic designed to justify an international intervention [37]. Additionally, objects of analysis are formed partly by discourse that describes them and do not exist naturally [39].

A key construct in these problematics is the principle of governmentality in which societies, economies, and government bureaucracies respond in reflexive, straight-forward ways to policies and plans. The notion of "governmentality" and its discourse suggest that state control is determinant ([37], p. 64). The state apparatus is deemed neutral and appears as an apolitical machine for implementing development projects as it represents "the people," often described as a homogenous group. Governmentality exhibits the extreme state-centeredness of development discourse because it assumes that there is no other way to improve [37]. This narrative is relevant to REDD+ because coordination and funding is only directed to the state rather than communities, CSOs, and other stakeholders. From the beginning of the UN-REDD program, the UN Framework Convention on Climate Change (UNFCCC) set up the state as the primary planner and implementer of the programs on a voluntary basis. Thus, States are not only seen as the most legitimate actor to implement REDD+ and improve rural community livelihoods, but the only way to intervene from an international perspective.

However, like other institutions, government is always an exercise of power [37]. The state has two functions: formally, to deliver social services, and informally, to use power to benefit some over others [37]. As a result, political turmoil and politics are absent in discourse, where "the people" are undifferentiated. Political and structural causes of poverty are systematically erased and replaced with technical ones, and the "modern" capitalist nature of society is systematically understated/concealed [37]. Simultaneously, international development discourse sets up "an object, out there, not part of the study but external to it" and itself as "an expertise and intelligence" that are entirely separate [39].

Neoliberal environmentalism, in a manner similar to the development industry, relies on technical "experts" to function and legitimize apolitical interventions [40]. Environmental neoliberal interventions are often depicted as common sense, objective or neutral through a process of depoliticization, or "to remove issues from political contention" [33], as opposed to value-laden and normative, political, issues due to considerations of equity and justice [40]. "Expert knowledge," then, becomes a way to empower market actors and others while marginalizing locals and context-specific concerns [41]. These conceptual frameworks are heavily used throughout the analysis of this study. 


\section{Results and Discussion}

The analysis for this paper draws heavily from examples in international development, particularly the work of Ferguson who examined the implications of apolitical interventions in Lesotho. As in his work, this research recognizes that structures are multi-layered, polyvalent, and often contradictory that often overtake intentional practices. In this way, intentional plans are never fully realized as "outcomes of planned social interventions can end up coming together into powerful constellations of control that were never intended [ ... ] but more effective for being subject less" ([37], p. 19). Outcomes that seem as side effects of unsuccessful attempts become "instrumental effects" that are instrumental in some other aim [38]. Ferguson demonstrates that development projects "squash political challenges to the system by enhancing powers of repression, and reposing political questions of land, resources, and jobs as technical" ([37], p. 270). The instrumental effect of these programs was to strengthen the power of the state as a powerful source of funds and site of patronage [39].

Ferguson contends that state expansion, as an instrumental effect, is not intentional nor centralized [37]. The state does not "rationalize and centralize" power relations, rather it "grabs and loops around existing power relations to cinch them together like a knot" ([37], p. 274). Bureaucratic state power, then, is a mode of power that relies on state institutions but exceeds them. REDD+ operates in a similar way, depoliticization discourse and the notion of governmentality squash political challenges to the program and create disjointed policies at the national level which establishes REDD+ as an unsustainable conservation fad. The fad, then, allows for the expansion of the state.

\subsection{Formation of REDD+ Discourse: State-Centered Technical Interventions \\ 3.1.1. Competing REDD+ Narratives}

Critical political ecology needs to consider the framing of discourse to legitimize intervention. Discourse is a "shared way of apprehending the world" that relies on assumptions, judgements, and contentions ([42], p. 8). It is critical to examine discourse because those who subscribe to it interpret information in a certain narrative or account [42]. In this section, the dominant and critical discourses and corresponding storylines that have been drawn out of policy discourse, and how REDD+ has evolved as a result are traced. These narratives frame REDD+ interventions and have become integrated together at the international and national level.

Ecological modernization is the dominant discourse that frames REDD+ thinking and policy practice in negotiations, drawing support from UNEP, FAO, and the World Bank in their operationalization of REDD+ [43], as the program primarily commodifies forestcarbon and encourages restructuring forest-people relations towards market-oriented public-private partnerships [19]. Ecological modernization (EM) scholars advance that EM provides a coherent framework that incorporates market and monetary processes and redefines the role of the state and markets in environmental reform beyond narrow neoliberal confined [44]. However, critics continue to emphasize that EM has a technocratic outlook, maintains the continuity of the capitalist order, which is fundamentally at odds with environmental prosperity, and prefers light touch green reformist approaches [44]. Principally, ecological modernization discourse still posits a largely market-focused orientation (even if it advocates for different models and approaches for connecting diverse actors, sectors, and institutions) as the primary solution for environmental externalities. It cements the role of the market and technological innovation to be able to reverse the negative impact economic development has had on the environment (Nielsen 2014).

On the other hand, civic environmentalism, while a heterogeneous term, brings concerns of environmental justice, ecological sustainability, equity, local knowledge systems and the inclusion of local stakeholder participation. This discourse is critical of EM's mainstream discourse and its reliance on markets and technical experts to solve environmental problems, and instead emphasizes relations of power between actors [23]. Civic environmentalism questions the "win-win-win" storyline of ecological modernization, arguing that community-based conservation inherently involves trade-offs and highlights 
the disjuncture between ideals of poverty alleviation and actual practice [19]. Furthermore, some civic environmentalists argue that community-based conservation is just a tool for the expansion of neoliberalism to further capital accumulation into rural areas [19].

Civic environmentalism values social and environmental safeguards more than the commodification of forest carbon fluxes [23]. EM discourse, conversely, suggests that the reason deforestation occurs is primarily a consequence of market failure within the forestry sector and the undervaluing (in economic terms) of carbon, which disincentives local communities from favoring forest conservation. The solution, therefore, is to create a carbon market and "teach" local communities the economic value they can receive from retaining carbon in standing forests. The solution is technical and apolitical and ignores issues of power. In contrast, civic environmentalism centers power and non-Western knowledge. It places politics between the North and South and their power relations as a key driver, for which local knowledge and holistic valuation could be a solution. Table 1 below showcases common storylines associated with both civic environmentalism and ecological modernism in REDD+ discourse.

Table 1. Storylines for Ecological Modernization and Civic Environmentalism (based off Nielson 2014).

\begin{tabular}{cc}
\hline Ecological Modernization & Civic Environmentalism \\
\hline $\begin{array}{c}\text { Cost-efficiency: reducing deforestation is most } \\
\text { cost efficient mitigation strategy for } \\
\text { climate change }\end{array}$ & $\begin{array}{c}\text { Beyond markets: emphasis should be on equity } \\
\text { and legitimacy rather than effectiveness } \\
\text { and efficiency }\end{array}$ \\
\hline $\begin{array}{c}\text { Win-win-win: REDD+ helps reduce emissions, } \\
\text { improve forest conservation, and } \\
\text { reduces poverty }\end{array}$ & $\begin{array}{c}\text { Beyond markets: REDD+ involves trade-offs } \\
\text { between economic growth and sustainable } \\
\text { forest management }\end{array}$ \\
\hline $\begin{array}{c}\text { Market rationale: market is key to internalize } \\
\text { environmental costs due to innovation in } \\
\text { private sector }\end{array}$ & $\begin{array}{c}\text { Local, not global: local knowledge not } \\
\text { adequately used during policy process }\end{array}$ \\
\hline $\begin{array}{c}\text { Carbon accounting: forests are subject to } \\
\text { management and control through } \\
\text { technical advances }\end{array}$ & $\begin{array}{c}\text { Biodiversity: problematizes valuing forests } \\
\text { purely for carbon }\end{array}$ \\
\hline $\begin{array}{c}\text { Technocratic rationale: societies can manage } \\
\text { environmental cycles, so carbon becomes } \\
\text { governmental/political domain }\end{array}$ & $\begin{array}{c}\text { North-South divide: countries in South lose } \\
\text { control of forestland, allowing North to defer } \\
\text { responsibility for mitigation }\end{array}$ \\
\hline
\end{tabular}

\subsubsection{REDD+ Discourse}

Before REDD+ emerged in international law, the link between forests and carbon were situated within scientific inquiry. In 2005, at the Coalition for Rainforest Alliance in Papua New Guinea, an official document claimed deforestation as "the single largest source category of emissions in the developing world" and that "without a more complete market valuation, standing forests cannot overcome the economic opportunity costs associated with their conservation" [45]. Low- and middle-income countries with high concentrations of forest advocated for a program that would compensate for their conservation while mitigating carbon and ensure common but differentiated responsibilities (CBDR). It was called "RED." RED continued to evolve to include reducing forest degradation (REDD) and role of conservation, sustainable management of forests, and enhancement of forest carbon stocks (REDD+). Table 2 outlines key COP provisions related to both ecological modernization and civic environmentalism narratives. 
Table 2. Narratives in official REDD+ discourse.

\begin{tabular}{|c|c|c|}
\hline Conference & $\begin{array}{c}\text { Elements Derived from Ecological } \\
\text { Modernization }\end{array}$ & $\begin{array}{l}\text { Elements Derived from Civic } \\
\text { Environmentalism }\end{array}$ \\
\hline $\begin{array}{l}2005 \text { Coalition for Rainforest } \\
\text { Alliance in PNG }\end{array}$ & $\begin{array}{l}\text { Market valuation } \\
\text { Economic opportunity costs }\end{array}$ & - \\
\hline COP 13 (2007) & $\begin{array}{c}\text { Technology transfer } \\
\text { Mobilization of resources }\end{array}$ & Sustainable forest management \\
\hline COP 16 (2010) & $\begin{array}{l}\text { Framework for conservation of forest } \\
\text { carbon stocks } \\
\text { Enhancement of forest carbon stocks }\end{array}$ & $\begin{array}{l}\text { Environmental and social safeguards to } \\
\text { protect or avoid risks while } \\
\text { promoting benefits } \\
\text { Alternative policy approaches for integral } \\
\text { and sustainable management of forests }\end{array}$ \\
\hline COP 17 (2011) & Financing options for results-based actions & Transparency and effectiveness of safeguards \\
\hline COP 18 & & Methodological issues of non-carbon benefits \\
\hline COP 19 (2012) & $\begin{array}{l}\text { Measuring, reporting, verification (MRV) } \\
\text { National forest monitoring systems } \\
\text { Encouraging public-private partnerships }\end{array}$ & $\begin{array}{l}\text { Governance and measures to ensure social } \\
\text { and environmental benefits and coordination } \\
\text { of support and institutional arrangements }\end{array}$ \\
\hline
\end{tabular}

As seen in Table 2, the core problematization of power for civic environmentalism discourse (local, not global storyline and North-South divide) is replaced by technocratic interventions when the narratives enter into the international framework. Where equity and legitimacy were key aspects of the beyond markets storyline for civic environmentalism discourse, technical social safeguards take their place. The result is a REDD+ program that "administrates" and "governs" an intervention rather than addressing concerns of equity, legitimacy, and local knowledge. In this way, the REDD+ official discourse mirrors Ferguson's development discourse by rendering deforestation apolitical.

These COP decisions also solidified the need for technical experts, particularly in forest carbon stock and monitoring, evaluating, and verification. The emphasis on resultsbased funding also ensures a slow process, requiring national-level frameworks well established after high-level dialogue, sizeable initial investment, and forest carbon as central to programmatic success.

\subsubsection{REDD+ in Ghana}

Ghana, the first REDD+ program in West Africa, began to develop a national REDD+ strategy in 2008 and submitted its final REDD+ strategy in 2016. Ghana's REDD+ strategy has been designed to directly meet requirements of the Warsaw Framework on REDD+ and other COP decisions. It integrates key frameworks, particularly from the Warsaw Framework, encouraging public-private partnerships, information sharing, results-based payments and actions, technical expertise and assessments, carbon market, safeguards, forest monitoring systems/MRV, and non-carbon benefits [46]. Ghana's vision for REDD+ is "to significantly reduce emissions from deforestation and forest degradation over the next twenty years, whilst at the same time addressing threats that undermine ecosystem services and environmental integrity in order to maximize co-benefits from forests" [46].

Discursively, ecological modernization and civic environmentalism are integrated at the international and national level to a certain extent. Without focusing on the power and agency of various stakeholders, and pursuing apolitical interventions, depoliticized critical discourse obscures its own aim. Competing narratives result in integrated discourse and finally practice, all the while losing an emphasis on power that rooted the first discussions. REDD+ in Ghana depoliticizes and deemphasizes civic environmentalism in the problematization of deforestation and the implementation of social and environmental safeguards. However, these components still legitimize a market-based forest carbon mechanism that all actors on the ground acknowledge is not politically or economically feasible. 


\subsection{Depoliticizing Drivers of Deforestation}

The goal in REDD+ discourse is to make Ghana a promising candidate for technical forestry intervention. To frame a "forestry apparatus" for a REDD+ intervention informed under UNFCCC, the national government needs to be a neutral instrument for a solution rather than a part of the problem $[37,39]$. As Hajer notes, environmental conflict is not due to a specific predefined problem between actors, but rather "a complex and continuous struggle over the definition and the meaning of the environmental problem itself" ([47], p. 5). The production of knowledge and discourse is ultimately a display of power, of complex social and political influences. Ghana's REDD+ strategy, likewise, attempts to depoliticize the problem of deforestation, particularly by side-lining market and tenure factors which would implicate the state.

Ghana's REDD+ strategy focuses on eliminating illegal activities that contribute to deforestation rather than addressing the market and policy factors that create illegal markets. Ghana's REDD+ strategy claims that it is "well-anchored within a favorable policy environment due to the National Climate Change Policy (2013) and the National Forest and Wildlife Policy (2012), which is foundational to REDD+ implementation" [46]. However, the legal framework has yet to recognize individual and collective management rights nor sufficiently regulate the timber market. The REDD+ strategy document also lists the indirect drivers of deforestation, including population growth and development, global markets, weak law enforcement, tree tenure and low stampage prices ([46], p. 31). However, the main drivers of deforestation are the "primary" criteria for assessing strategy options, which gives more weight to them over structural and political causes of deforestation ([46], p. 32). While these underlying drivers are minimally acknowledged, they are consistently minimized.

\subsubsection{Land and Tree Tenure as Deforestation Driver}

Throughout Ghana's REDD+ strategy, legal reforms in the land and tree sectors are constantly de-emphasized, thereby largely placing the fault for deforestation on local communities for illegal harvesting and agricultural practices. For example, REDD+ gives three primary interventions to counter deforestation in Ghana, ranked by urgency. The first two are targeted towards the practices of local communities, including improving land use and addressing wood harvesting and agricultural practices. Policy and legislative reforms are last on the list. In REDD+ strategy documents, Ghana was given a "further development required" in legal reform because policies have not been translated into legally binding laws - particularly tree and carbon tenure [48]. Yet, the "next steps" for the progression of REDD+ fail to mention legal reform as a prerequisite for REDD+ readiness. This section demonstrates how land and tree tenure are underlying causes to deforestation and forest degradation, as communities lack ownership and management rights to their natural resources.

There are three types of land in Ghana: natural parks, on-reserve, and off-reserve. REDD+ largely targets off-reserve communal land to diminish deforestation and forest degradation. Community off-reserve land are often vested in chiefs, and off-reserve exchanges of land require authorization from them, accounting for control of approximately $80 \%$ of the land in Ghana Prior to British colonial rule, much of the land in Ghana was communally owned without official title/deeds. Then, in the late 18th-century colonial era, customary law accredited people with legal capacity to carry out valid alienation of group-held property [49]. Chiefs or heads of families were usually the accredited individuals. As communal property became seen as chief's property over the years, industry developed on the land in the form of permanent cultivation, mining, and timber. Due to these first efforts to cement private land tenure, chiefs gained communal lands and partnerships with key industrial, colonial actors, leaving local farmers with little opportunity to accumulate wealth.

The 1983 International Monetary Fund and World Bank structural adjustment programs further exacerbated the accumulation of land management by shifting property 
from communal to individual ownership [49]. The privatization of land, structured around neoliberal rational of markets and private actors, gave most land management power to chiefs as individual owners. Land tenure was inundated by insecurity of title, especially as the population began migrating from the countryside to the city and increased land transactions [49]. Land insecurity is a primary driver for deforestation and forest degradation in these regions, but it is largely because communities are not aware that the chiefs should manage the land for them, and they have customary rights over these areas. Instead, they are largely seen as the chief's private property, thereby perpetuating alternative livelihoods into forest areas. This could improve with Ghana's Land Act (Act 1036) enacted in 2020 which requires chiefs to be transparent, fair, and impartial in making decisions over land. However, it still does not give customary land tenure, including management and use rights, back to communities. Land tenure insecurity, especially the accumulation of land by chiefs to use for private gain, is an underlying cause of deforestation and forest degradation that REDD+ does not address.

The lack of secure tree tenure for local farmers also fuels deforestation and forest degradation in Ghana. There are two legal categories for trees in Ghana: planted and naturally occurring Tree tenure includes right to own or inherit, right to plant, right to use, and right of disposal. The state hold, or appear to hold, ownership and management rights due to lack of clarity in the law, misinformation, and lack of communal governance. Ghana's 1962 Concession Act vests timber resources and naturally occurring timber trees in the President of the Republic of Ghana on behalf of the People of Ghana [50], although forest-owning communities assumed their ownership rights had been lost to the State [51] The 1992 Constitution vests naturally occurring timber in the president but in trust for the stools (chiefs) concerned, which is to be managed by the Forestry Commission in recognition of pre-existing customary rights [52].

While farmers own and manage planted trees, they have no ownership or management rights of naturally generated trees, even on their private property. Naturally occurring trees still require the same amount of management as planted trees. It is illegal for farmers to sell timber from naturally occurring trees from their land, instead they can only use it for subsistence purposes. Yet, timber companies can access trees on their land (Director, PAB Development Consults). Hence, farmers have an incentive to cut trees down, burn them, and/or sell them to illegal chain saw operators, which fuels deforestation and perpetuates the illegal timber market. It is important to note that illegal chain-saw operators buy timber at a lower rate than the legal market, meaning that farmers lose that potential income by selling it illegally.

To tackle illegal logging, legal reform is necessary to give individual farmers ownership and management rights of naturally occurring trees on their farms as well as community's explicit ownership and management rights of forest reserves. The 2012 Forest and Wildlife Policy was formed during the REDD+ negotiations and attempted to incorporate individual and collective benefits for tree tenure. It says "to enact legislation that will allow communities/individuals to benefit from trees on their land. Benefits accruing from resources individually and collectively" [53]. While benefitting from forest resources individually and collectively is an important component of reducing deforestation, it does not give individuals or communities explicit ownership or management rights of forests. Furthermore, the 2012 policy contradicts the 1962 Concession Act. Meaning, the 1962 Concession Act would need to be repealed in order for the 2012 Forest and Wildlife Policy to have legislative backing and come into effect. The Tree Tenure Reform, submitted in 2016, is the latest attempt to ensure "ownership of naturally occurring timber trees off reserve are vested in the communities and stools concerned," but there is little hope for it to be adopted [51].

Politics and power are central to why these reforms have yet to take place. The Director of PAB Development Consultants, who drafted the Tree Tenure Reform for the Ministry of Land and Natural Resources, notes that he has been involved with tree tenure reform for 25 years, and "there have been so many policy reform discussions in the sector that have 
not seen the light of day. I'm not very optimistic that any major reforms are going to take place because there's too much vested interest in the sector" (Director, PAB Development Consultants). Yet, Ghana's REDD+ strategy frames legal reform as probable ([46], p. 62). For communities to benefit from forest resources, the State and chiefs would need to give up some of their power. The State would have to implement legal reform, mandating naturallyoccurring trees to individuals and ownership and management rights to communities for off-reserve community forests. Further, politics and timber are interconnected, as the private sector funds political campaigns (Director PAB Consulting). Chiefs, who benefit from the misinformation and management rights, are well respected and powerful "so no government wants to have conflict with chiefs." Ghana's REDD+ strategy depoliticizes legal reforms in the land and tree tenure sector, which allows the state and chiefs to maintain ambiguous control of these resources and leaves local communities without sustained access to forest resources that they need for their livelihoods.

\subsubsection{Timber Market as Driver of Deforestation}

Ghana's REDD+ strategy defines the problem of deforestation as local, rather than driven by domestic timber market factors (quotas, ease of access, etc.) set by the national government. Yet, the domestic market for timber in Ghana makes it difficult and expensive for Ghanaians to access legal timber markets. Present laws are not workable-usually the nearest sawmill that sells domestic timber is distantly located, and the timber market is not decentralized to district and local levels. Additionally, Ghana set the quota for export timber at $70 \%$ export, leaving 30\% for domestic consumption. Local demand exceeds $30 \%$ of timber produced, which creates the conditions for illegal timber markets. The Programs Officer for EcoCare Ghana estimates that 7/10 domestic lumber comes from illegal sources. Even though timber companies pay the same stampage fees for domestic and international markets, they make a higher profit selling on the international market and the state can charge higher taxes. So, the state has an incentive to maintain the high export quota, regardless of the demand for timber in the domestic market. Without addressing the accessibility for domestic timber and reforming export/import quotas in Ghana, the illegal timber market will continue.

In order to curb deforestation and forest degradation, land and tree tenure need to be equitably secured by communities, including ownership, management, and use rights. Additionally, the domestic timber market needs to have a higher quota to meet demand. The necessary reforms, which would diminish state financial resources, contradict the "win-win-win" storyline of environmental modernism, and instead demonstrates the trade-offs in national economic growth and sustainable forest management, outlined by the beyond markets storyline of civic environmentalism discourse which is not present in official REDD+ discourse. The objectives of the program do not target these structural causes of deforestation due to their political nature, which would cut into the financial resources of the state. The timber market and tree tenure are not sufficiently addressed in the REDD+ strategy because the state has an incentive to maintain its power and resources, thereby contradicting the premise of a neutral state.

\subsection{Depoliticized Social and Environmental Safeguards}

Civic environmentalism discourse has largely led to the inclusion of social and environmental safeguards in neoliberal interventions, with explicit links to transparent governance and inclusionary participation [19]. Environmental and social safeguards have been set up to ensure that Ghana's REDD+ strategy "does no harm" to local farmers and populations, following the World Bank's requirements that were developed from UNFCCC guidelines ([46], p. 66). One social safeguard that is based on the "beyond market" storyline that emphasizes equity and legitimacy is the "full and effective participation of all UN-REDD Program stakeholders-partner countries, donors, indigenous peoples, civil society organizations, participating UN agencies-while ensuring streamlined decisionmaking processes and clear lines of accountability" [54]. 
However, the deemphasis on power relations renders this social safeguard impotent. Further, the differing political interests of stakeholders are not accounted for in negotiations. REDD+ in practice in Ghana questions whether civic environmentalism discourse can be effectively integrated into programs largely concerned with technical social interventions that ignore the political roots of inequalities between stakeholders. Once again, this depoliticization of participation allows powerful actors, such as the state, to ultimately remain in control of the decision-making process to maintain their own power and resources.

\subsection{1. "Full and Effective" Participation of Communities}

Ghana has included an approach "that prioritizes the need for an accountable and participatory process with effective participation of women and local communities" ([46], p. 66). First, participation does not guarantee governance or decision-making power, it only allows the discussion between various stakeholders. The official stakeholders are civil society, the private sector, government, research and academia, and development partners, whilst communities are noticeably absent as stakeholders ([46], p. 71). Nuances of social systems, politics, and history are not considered to ensure "full and effective participation." Instead, these processes are co-opted to legitimize that focus on technical rather than systematic interventions. REDD+ safeguards in Ghana overlook the political and competing interests of actors. The lack of financial resources and time also limit REDD+ from gaining "full and effective" participation from communities (REDD+ consultant).

Communities have limited, if any, participation in high-level decision making. REDD+ in Ghana has progressed fast at the national level, but communities lack an understanding of what policies were decided (IUCN officer). While a participatory forestry governance mechanism in Ghana was set up by civil society to bring local representatives to engage at the national level — the National Forestry Forum (NFF) - it lacked the funding to continue (Programs Officer for EcoCare Ghana, Programs Officer for Forest Watch Ghana). NFF has not taken place in over two years. Without the NFF, the Climate Change Unit has difficulty deciding which communities to include in consultation, so community representatives end up being random or politically motivated rather than representative (Safeguards Working Group member). As a result, communities are not represented in Ghana's MultiStakeholder Implementing Communities (MSIC), the highest level in policy development.

When local representatives are included in the discussion, they are not "effective" collaborators because of unequal technical knowledge of REDD+, and thus lack the capacity to contribute effectively to the Working Groups, particularly in the MRV working group (Programs Officer for EcoCare, Country Coordinator for IUCN, National Deputy Director for ROCHA). This affirms Nielsen's limit of civic environmentalism that assumes a participatory process based on different power dynamics is even possible [23]. By depoliticizing the participation of stakeholders, REDD+ Ghana allows for powerful, decision-making actors to maintain power.

What happens in most cases is that communities are represented instead, in nationallevel committees and sub-working groups, by traditional authorities and civil society organizations. It is assumed that the interests of these stakeholders align with those of communities and hence the community voice will be well represented, yet that it is not necessarily the case [55]. Civil society organizations may be pro-industry, who would seek large areas of land for REDD+ projects, or pro-community, who would protect community rights to land (Program Officer, Forest Watch Ghana). Additionally, civil society representatives recognize that they cannot represent community interests (Program Officer, EcoCare). Additionally, chiefs are often invited to represent community interests in REDD+ negotiations as powerful actors. However, as outlined earlier, chiefs often have different interests from the communities largely due to a history of dispossession of communal land. Selecting chiefs as community representatives loses a sense of transparency and accountability in the negotiation process (Officer, Casa Watch Ghana).

Similarly, actors at the community level are taken as a homogeneous group, when, in practice, there are divisions of interest. In the cacao farms in South-western Ghana, 
tenant farmers are some of the most vulnerable in Ghanaian society, yet they are not represented in community REDD+ processes because they do not have customary titles (Officer, Casa Watch Ghana). In national-level policy meetings, issues with tenant farmers are not represented, especially if it is a traditional authority who is summoned (Officer, Casa Watch Ghana). These traditional authorities have been consulted in every aspect of REDD+, as a result they automatically receive $2 \%$ of benefits from carbon market.

The State ultimately makes decisions about REDD+ as the most powerful actor, especially because UN-REDD program funds flow directly through the state without any funding mechanism for other stakeholders. Ghana's REDD+ strategy acknowledges that the national government will "play a lead role" during policy and legislation discussion, but the discourse assumes that the State equally values perspectives from other stakeholders. The State engages with other stakeholders in discursive participation but ultimately decides based on their own interest (Country Coordinator for IUCN). This demonstrates the limit of the notion of governmentality and the "full and effective" participation safeguard, which does not transfer ownership or management of the program to local communities who are the primary beneficiaries of the program. Instead, it assumes that the State "represents the people" in an apolitical manner.

Ghana's REDD+ strategy overlooks historical and political power in favor of a policy that paints them all as equally effective actors with common interest, just as discourse in development projects conceptualizes "the people" as an agglomeration of individuals, thereby reducing political and structural causes of poverty and layers of society [37]. Ciplet and Timmons point out that environmental neoliberalism has increased over time in international environmental governance of climate change, thereby negating precautionary and equity-based concerns: "The neoliberal pursuit of transparency is not preoccupied with other political goals such as democracy, empowerment of diverse stakeholders, and improved governance, but is instead used to preempt stronger, compliance forms of regulatory action (Roberts 1998; Haufler 2010), reinforce neoliberal norms of individual responsibility (Mason 2008), and elevate concerns of powerful actors over others under a veil of neutrality" ([40], p. 151). Furthermore, Scheba and Schebab describe this veil of neutrality as "inclusionary" discourse and practices in REDD+ to legitimize new markets without regard to power imbalances and structural inequalities [19]. These authors therefore "question the emancipatory power of 'inclusive' practices that actively script-out larger historical context and insufficiently recognize it as an uneven playing field" [19]. In this way, REDD+ democratic engagement of participation paradoxically deepens the processes of depoliticization by overlooking "the underlying political economic dimensions of poverty and exclusion" ([19], p. 528)

\subsubsection{Consistent Actions with National Forest Programs}

The first social and environmental safeguard of REDD+ is "consistent actions with national forest programs." It is key to note that this discourse is already depoliticized because it does not say "consistent actions with national programs," implicating cohesive programming with extractive industries and other competing interests. Regardless, all interviewees agreed that REDD+ must not be implemented as a separate stand-alone program, but rather integrated into the national forestry governance landscape. By establishing REDD+ within the Forestry Commission, as opposed to setting up a new system, there is some sustainability and continuity (Director of Climate Change Unit). Additionally, the safeguards feedback and grievance mechanism, which will receive and address any project-related complaints, can be used to address forestry complaints beyond REDD+ (Program Director, Tropenbus Ghana).

However, integration of programs is not sufficiently combined due to competing interests. REDD+ has brought funding to the Climate Change Unit, but other departments within the Forestry Commission that are essential for sustainable forest management are "starving of resources, such as the wildlife department" (Deputy Director for ROCHA). Additionally, the Forestry Commission has not adequately integrated two separate international initiatives - the REDD+ secretariat under the Forestry Services Division and Forest 
Law Enforcement Governance and Trade (FLEGT) under Timber Validation Department. The Programs Officer for EcoCare Ghana sees this conflict problematic particularly at the community level, where farmers will choose between both programs to participate, whether to choose timber or carbon which will always result in timber.

Additionally, although 47 district-level offices are key components of REDD+ implementation, information about REDD+ is not well dispersed throughout the district levels, and funding to implement education programs to the communities does not trickle down to the regional or district level. While the Forestry Commission has the institutional capacity to decentralize REDD+, it still has not happened (Officer, Care International). After 10+ years of negotiation, REDD+ still operates from a national level.

The lack of integration at the state level is the result of competing interests within government agencies, which reflects the notion of government as an exercise of power [37]. Contradictory and incoherent policies and programs allow for the State to accomplish its second, informal goal- to use power to benefit some over others [37]. Additionally, international fads in forestry create transient government priorities to acquire funding. The depoliticization between forestry sectors and state agencies create disjointed policies in REDD+ practice. The shifting international and government priorities is another reason that local communities should have governance and management rights over their forests. Legal reform, as already shown, is highly unlikely.

\subsection{Forest Carbon Market Acquires State Funding without Benefitting Communities 3.4.1. Commodification of Carbon}

Neoliberal environmental conservation models move environment and social relationships into the realm of commodities, connect to the carbon accounting storyline of ecological modernism [56]. REDD+ sets the market for a newly establish commodity, forest carbon [24]. The justification for forest carbon as a means to diminish deforestation and forest degradation is deeply rooted in ecological modernization, especially the market rationale and carbon accounting storylines. The measurement of carbon forest is a prerequisite for commodifying avoided deforestation, which is estimated based on the forest's biomass [24]. A forest monitoring system was established that combines remote sensing technology with ground-based sampling to estimate carbon emissions reductions and removals. Reference levels create a baseline to measure emissions reductions compared to "business as usual" projections, which include deforestation, degradation, and carbon stock enhancement ([46], p. 78). Emission Reductions Payments are calculated by social performance indicators and emission reduction indicators ([57], p. 27).

REDD+ uses an already established metric, the ton of carbon dioxide equivalents (tCO2e for short). The performance of REDD+, which determines future payment, is based on emission reductions, a calculation of tCO2e. These calculations are the basis for defining successful outcomes and progress. Ghana's National Climate Change Policy Master Plan defined progress in terms of carbon sinks and carbon stocks ([46], p. 84). However, academics have contested the measurement of forest carbon through baselines estimates, thereby questioning the legitimacy of its commodification [58]. Given the complexity and creation of a commodity that does not physically exist, there is high uncertainty in the carbon market. Marx defines a commodity as a physical thing that satisfies human needs in exchange for something else, as something that has use value, exchange value, natural material, and labor [56]. Yet, tCO2e is not a physical thing nor is it a natural material. It only has an exchange value, so the baseline can be inflated during calculation. This section demonstrates how uncertainty, low price, and high cost of accounting make economic benefits of forest conservation negligible for local communities, while bolstering the State's budget.

\subsubsection{Carbon Payments and Results-Based Funding}

To achieve $100 \%$ performance for REDD+ Ghana, there must be 10 million tCO2e emission reduction worth US\$50 million for the period 2018-2024. In this scenario, US\$2 
million will cover fixed costs, US\$1.44 million as a performance buffer, US\$33.465 million for communities and authorities, and US\$13.095 million for the government ([57], p. 28). The funding system is results-based, strictly on reduction in emissions as "only verified reductions in deforestation and degradation will trigger carbon payments from the FCPR-CF to be stared between identified beneficiaries" ([57], p. 23). The results-based financing, which requires strong reporting, is posited as "one of the main differences between traditional development project models and REDD+" ([46], p. 72).

The carbon market and carbon accounting are prioritized by REDD+ because of "results-based funding," which also means that most of the REDD+ readiness funding is diverting for Monitoring, Verification, and Reporting (MRV). Several interviewees name $\mathrm{MRV}$ as the greatest challenge to REDD+ in Ghana, particularly because it requires regulatory data collection every five years. This means that external funding is necessary to keep up with MRV, especially as the government is not likely to pay for it if they do not have a financial interest (Director of PAB Development Consultants).

Given the operational costs of MRV, there is little funding left for other aspects of REDD+, such as participatory governance. MRV is by far the most expensive aspect of the REDD+ program, accounting for US $\$ 1,140,000$ out of US $\$ 1,990,812$, or $57.26 \%$ of the fixed costs of the program from 2019 to 2024. The next most expensive item is consultants that account for US $\$ 180,000$, or $9.04 \%$ of the overall fixed costs ([59], p. 25). Consultants, or technical experts, are also largely required for the MRV process. The financial resources are spent on travel to international conferences (Deputy Director, ROCHA).

Even with the expense of measuring forest carbon, communities do not see the benefit of "selling" forest carbon due to the complicated accounting and low price of carbon. All interviewees noted that individual monetary carbon payments would be ideal as it would incentivize farmers to keep trees on their off-reserve farm. However, individual carbon payments are not enough to incentivize local farmers to not cut down trees as timber (Ghana's REDD+ strategy staff). Given the choice between competing commodities (timber, coco) directly, farmers would not save trees for carbon. Yet, the cost of MRV and carbon accounting make individual payments for carbon impossible. To commodify carbon for individual benefits, it would require assigning carbon benefits to specific trees (Program Officer Tropenbus). The accumulation of carbon is not the same for every tree in the same landscape, which makes it more complicated than the timber analogy (Professor of Forestry, Kwame Nkrumah University). Therefore, the amount of work required to generate biomass carbon stock of each tree in the landscape would surpass the money coming in terms of operational costs (Professor of Forestry, Kwame Nkrumah University). The low price of carbon also makes it so that households will likely not gain a significant amount of financial incentive for participating in REDD+ (Country Coordinator for IUCN).

Due to the low price of carbon on the carbon market and complexity of carbon accounting for individuals, Ghana's REDD+ strategy decided on collective instead of individual benefits in which communities have a fund to use for community projects. The community benefit-sharing system sets up community development programs for services that the state should provide. As a Program Officer for Forest Watch Ghana notes, "they're giving fertilizers anyways. They're building hospitals anyways. But if you look at REDD+ carbon scheme, they will say they will use carbon money. But it's something they're supposed to get in the first place". So, these services are promised to be paid for by the state and the carbon payments, meaning that the state can pocket the excess funds. Government can use the carbon money to finance its own national budget (Program Officer, Forest Watch Ghana). In this way, REDD+ provides another avenue for the state to gain financial resources.

\subsection{Co-Benefits: Where Discourse and Practice Align Temporarily}

Emission Reductions Payments are only based on tCO2e emissions that do not incorporate non-carbon benefits. Due to commodification of carbon, every other value and articulation of forests lose meaning. In other words, forests become "carbonified" [24]. 
Corbera notes that forest carbon could render invisible interconnectedness of ecosystem elements, an expressed concern by several CSO representations [60]. Yet, REDD+ is only viable with policies to address deforestation without undermining livelihoods [60]. Of course, forests have a wider spectrum of values to local communities beyond their carbon storage capacity. They are necessary for livelihood strategies, household firewood, source of wood, a site of biodiversity, or as a recreational space. The biodiversity storyline of the civic environmentalism discourse exemplifies this concern well, noting that forests should not be valued solely for their carbon.

Due to the limitations of the REDD+ interventions that do not provide economic incentive to halt deforestation, Ghana's REDD+ strategy has adapted to focus on how else they can incentivize local farmers and communities to conserve forests outside of the international framework: ecosystem services and co-benefits to improve livelihoods. The Climate Change Unit credits the enforcement of safeguards measures to ensure biodiversity and ecosystem services "are given adequate attention" ([61], p. 76). The Climate Change Unit focuses on essential commodities that add direct value like coco to generate individual income for farmers. The co-benefit strategy allows for both financial and non-financial incentives for forest conservation. Given that farmers would not choose the carbon commodity over timber, cocoa, rubber, or any other commodity which has a stable, higher price and accessible market, Ghana's REDD+ strategy seeks to minimize the importance of carbon payments and highlight instead co-benefits (Director, Climate Change Unit). GCFRP noted that the "priority non-carbon benefits have the potential to carry the program, even if performance is low, and are meant to secure engagement in the program and success over the long-term (past the ERPA time-frame) ([61], p. 19)". All interviewees expressed that this was not only the best option, but the only feasible way to implement REDD+.

The World Bank formally accepted Ghana's Emission Reduction Program for the Cocoa Forest Mosaic Landscape in 2014, which seeks to reduce emissions driven by cocoa farming, other agriculture, illegal logging, and illegal mining [46]. Most coco is grown through smallholder farmers with an average of 1-hectare plot of land, so these farmers would directly benefit from increased yield (Head of Climate Change Unit). The program, then, is two-fold: restoring forests but also increasing yields. Ghana's REDD+ strategy Cocoa Initiative is the most advanced REDD+ program which has set up co-benefits, attracting the attention of both the private sector and farmers. Optimal yields come from incorporating trees into the cocoa landscape for shade, which will produce higher coco yield. Then, the farmers would also be less likely to encroach on forest reserves. The incorporation of trees also qualifies as a climate-smart condition for which buyers would be willing to pay premium prices.

Similarly, the GCF's REDD+ Shea Program in the Northern landscape will focus on increased income by targeting the supply chain (Global Shea Alliance Development officer). With access to storage infrastructure, the Shea Program will generate revenue 30-50\% more than the normal market price, which will become apparent in the 1st and 2nd shea season (Global Shea Alliance Development officer). Community members have noticed the depletion of these ecosystem services over time, which motivates them to protect biodiverse, sustainable forestry (Several interviews). While these ecosystem services are undervalued in international discourse around REDD+, Ghana's adaptive approach incorporates them.

However, the co-benefits system may not be enough to deter deforestation in Ghana. In the short term, REDD+ could be successful only because it will increase their yields, but these co-benefits are not a long-term sustainable forestry management plan (Care International officer). Land use will likely change in the long term in Ghana. For example, cocoa yields are predicted to drop again due to climate change and timber industry will increase to take its place, making Ghana's REDD+ strategy less of an incentive (Care International officer). Additionally, the co-benefits strategy overlooks that local communities and Indigenous Peoples likely already understand the co-benefits and livelihoods opportunities that the forests offer. REDD+ only connects them to the private sector for export-oriented goods rather than their customary livelihood practices. 
Additionally, the State can easily alter its current strategy of co-benefits. Competing state interests could use REDD+ to create environmental enclosures through territorialization for carbon conservation [60]. As Asiyanbi et al. note, rendering carbon visible renders others aspects of forests invisible, which could lead to aggressive government actions to pursue commodities (timber, carbon, cocoa) that provide the most financial gain to the state and politicians [32]. The co-benefits component of REDD+ may be advantageous right now for the private sector, government, and communities, but that may not always be the case. Without secure tenure and decision-making power for local communities, the State could easily shift its focus to more profitable land uses for them. Without a framing to ensure that local communities still have access to their land even if political and economic interests shift, co-benefits in REDD+ provide only temporary poverty alleviation dependent on international markets.

\subsection{Tracing Discourse and Practice}

Civic environmentalism was the root of official REDD+ discourse; however, the discourse renders the interventions purely technical and apolitical. In practice, the social and environmental safeguards allow the state to avoid responsibility for policies that encourage deforestation, ensure decision-making power, and acquire financial resources under the veil of social-ecological responsibility. The following two tables (Tables 3 and 4) summarize civic environmentalism and ecological modernization through debate narratives, official discourse, and the resulting practice that were outlined in the above sections.

As civic environmentalism moves from a debate narrative to REDD+ practice in Ghana, it becomes weaker. The debate narratives focus on power. It calls out the varying political power and responsibility in relation to the Global North-Global South divide as well as the local-global knowledge paradigm. The emphasis on equity and legitimacy, also, assumes that the status quo in forestry conservation is neither. It recognizes that some actors will need to "lose" some power in the event of a trade-off between economic growth and sustainable forest management.

Table 3. Civic environmentalism from discourse to practice.

\begin{tabular}{|c|c|c|}
\hline Debate Narratives & Official Discourse & In Practice \\
\hline $\begin{array}{l}\text { Beyond markets: emphasis should be on } \\
\text { equity and legitimacy rather than } \\
\text { effectiveness and efficiency }\end{array}$ & $\begin{array}{l}\text { Social safeguards: "full and effective" } \\
\text { participation }\end{array}$ & $\begin{array}{l}\text { "Full and effective" participation is not } \\
\text { adequately funded nor is there adequate, } \\
\text { informed, equal representation from all } \\
\text { stakeholders }\end{array}$ \\
\hline $\begin{array}{l}\text { Beyond markets: REDD+ involves } \\
\text { trade-offs between economic growth and } \\
\text { sustainable forest management }\end{array}$ & - & - \\
\hline $\begin{array}{l}\text { Local, not global: local knowledge not } \\
\text { adequately used during policy process }\end{array}$ & - & - \\
\hline $\begin{array}{l}\text { Biodiversity: problematizes valuing } \\
\text { forests purely for carbon }\end{array}$ & $\begin{array}{l}\text { Environmental safeguards: } \\
\text { Sustainable forestry management } \\
\text { Non-carbon benefits } \\
\text { "Consistent actions with national forest } \\
\text { programs" }\end{array}$ & $\begin{array}{l}\text { Receives no "results-based" funding; } \\
\text { incentivized through agricultural } \\
\text { programs and private-sector partnership } \\
\text { (co-benefits); inconsistent with other } \\
\text { forestry programs }\end{array}$ \\
\hline $\begin{array}{l}\text { North-South divide: countries in South } \\
\text { lose control of forestland, allowing North } \\
\text { to defer responsibility for mitigation }\end{array}$ & - & - \\
\hline
\end{tabular}


Table 4. Ecological Modernization: from discourse to practice.

\begin{tabular}{|c|c|c|}
\hline Ecological Modernization & Official Discourse & In Practice \\
\hline $\begin{array}{l}\text { Cost-efficiency: reducing deforestation is } \\
\text { most cost efficient mitigation strategy for } \\
\text { climate change }\end{array}$ & $\begin{array}{l}\text { "solving the deforestation problem is a } \\
\text { prerequisite for any effective response to } \\
\text { climate change" }\end{array}$ & $\begin{array}{l}\text { Operational cost of carbon accounting far } \\
\text { outweighs other mitigation strategies }\end{array}$ \\
\hline $\begin{array}{l}\text { Win-win-win: REDD+ helps reduce } \\
\text { emissions, improve forest conservation, } \\
\text { and reduces poverty }\end{array}$ & $\begin{array}{c}\text { "reduce emissions maximize cobenefits } \\
\text { leading pathway towards sustainable } \\
\text { development" }\end{array}$ & $\begin{array}{l}\text { Does not improve forest conservation } \\
\text { because lack of land and tree tenure nor } \\
\text { poverty alleviation becausecarbon } \\
\text { payments negligible and limited } \\
\text { decision-making power }\end{array}$ \\
\hline $\begin{array}{l}\text { Market rationale: market is key to } \\
\text { internalize environmental costs due to } \\
\text { innovation in private sector }\end{array}$ & Public-private partnerships & $\begin{array}{l}\text { Sustainable forestry management, not } \\
\text { carbon, helpful to cacao business }\end{array}$ \\
\hline $\begin{array}{l}\text { Carbon accounting: forests are subject to } \\
\text { management and control through } \\
\text { technical advances }\end{array}$ & $\begin{array}{l}\text { Monitoring, Verification, and Reporting } \\
\text { (MRV) }\end{array}$ & Difficult and expensive to calculate \\
\hline $\begin{array}{l}\text { Technocratic rationale: societies can } \\
\text { manage environmental cycles, so carbon } \\
\text { becomes governmental/political domain }\end{array}$ & Results-based funding & $\begin{array}{l}\text { Uncertainty in commodity } \\
\text { Local deprioritization of carbon }\end{array}$ \\
\hline
\end{tabular}

The three storylines that are most firmly rooted in local/global and North/South power dynamics are not present in the official discourse. The only two storylines present in formal discourse are beyond markets and biodiversity. Civic environmentalism is most strongly present in the social and environmental safeguards such as "full and effective" participation and "consistent actions with national forest programs." However, these are also depoliticized. "Full and effective" participation is taken as a positive social safeguard, but it does not ensure decision-making power or governance by all stakeholders, particularly for communities. In practice, the REDD+ program does not provide adequate funding to ensure "full and effective" participation. As a result, the state maintains control of the REDD+ process. Additionally, environmental safeguards are depoliticized so cobenefits are only prioritized in practice when interests align between the state, private sector, and local communities.

Contrary to civic environmentalism discourse which loses its funding and prioritization in practice, ecological modernization becomes much stronger. The official discourse touts cost-efficiency, carbon accounting and market to reduce poverty through technocratic interventions. In practice, the operational cost through MRV to estimate carbon accounting for a successful carbon market outweighs all other costs, only to provide small community projects as benefits. It does not create a market incentive. Rather, it renders deforestation technical and limits funding for other sustainable forestry measures and representative participation. It channels available resources to technocratic experts rather than those conserving forests. Ecological modernization becomes the ultimate dominant discourse with the implementation of results-based funding.

\subsection{State Expansion}

Development projects form interventions in terms of geography and nature rather than powerlessness and social inequality, on both the national and international levels [39]. So, alternative solutions are not strictly managerial and technical, but social and political, a reworking of the actors to redistribute power and wealth [39]. Similarly, Scheba and Schebab conclude that conservation practice needs to be politicized in a way "that does not lose sight of structural inequalities alongside micro-political struggles" [19]. By depoliticizing critical discourse, it becomes easier in practice for the State to maintain and even acquire power. Establishing REDD+ in Ghana as a "fad" that implements technical, apolitical interventions and disjointed governance maintains a gap in which deforestation is never addressed. Ferguson's analysis of a development program and problematic in 
Lesotho recognized this recurring gap as well, thereby arguing that the instrumental aim or effect of the program, then, was to expand disperse state power [37]. Similarly, Lund et al. note that the gap between discourse and practice "allow certain actors within development and conservation industry to tap into financial resources" [62].

In the case of REDD+ in Ghana, funding for the programs flow through state channels and largely stay at the high level where they are distributed to key powerful actorstraditional authorities, private sector, and certain civil society members. To access these funds, the State needs to adhere to international frameworks in a way that will ensure no loss of power over land, natural resources, or contradictory economic opportunities. Ghanaian national government uses REDD+ as "free money." At the same time that the State expands due to funding for REDD+, mainly through the REDD+ readiness program, it is able to maintain its revenue, power, and resources that fuel deforestation, such as lack of land and tree tenure for communities, high export timber quota, and contradictory forestry programs. The State does not have to sacrifice any interest in other revenue-creating industries in Ghana to implement the REDD+ program.

\section{Fortress Conservation}

As a result of State expansion, the key instrumental effect of concern for REDD+ Ghana is the cracking down on illegalities with methods of fortress conservation. To respond to illegal logging, Ghana policies have favored fortress conservation and enforcement of laws rather than more access to lumber or timber benefits, which would require reform in the sector and a loss in state power. As noted by Sefwi Wiawso officials, measures have been taken to disincentivize illegal logging by the State-including the Voluntary Partnership Agreement (VPA) that established a wood tracking system to make illegal timber transport more difficult and increase penalties for selling illegal logs to ten times the market price, which also would cancel your permit if left unpaid. These reforms have been put in place and have been used by the Forestry Commission (Sefwi Wiawso officials), but the stampage fees that are required for communities to benefit from timber are rarely enforced. At the two meetings between the Forestry Commission district officials, REDD+ national officials, and community members that I attended, the stampage fees were the greatest point of concern and frustration for community members. As mentioned earlier, REDD+ does not address the underlying, systemic, and political causes of illegal logging in Ghana, the State can use its newly acquired resources to further criminalize and prosecute illegal loggers and miners. The REDD+ program also allows the state to expand its governance and enforcement at the district levels, similar to the VPA program.

While enforcement of legal timber market is necessary, the tree tenure and legal, domestic market conditions are unfavorable for communities to have access or benefit from timber. As policies against illegal logging are adopted to deter locals from selling illegal timber and policies for timber companies to pay communities are not enforced, with the gap in domestic supply chain, communities are not likely to buy into Forestry Commission programs. Furthermore, without policies to address the underlying systemic problems with tree tenure and the market, deforestation will continue, and the State will adopt more and more aggressive stance against illegal logging.

\section{Conclusions}

In the case of REDD+ in Ghana, civic environmentalism discourse becomes weaker as it moves from narratives debates to official discourse and then practice. Social and environmental safeguards are rendered technical and lack funding, so in practice civic environmentalism discourse only serves to justify REDD+. At the same time, ecological modernism gains strength by defining results-based success and siphoning funding for commodification. This case shows the limits of critical discourse in international climate programs that largely derive from neoliberal environmentalism.

Official discourse ignored political and power dimensions and so rendered the intervention a purely technocratic process shaped by bureaucratic "governmentality", largely 
due to the state-centric nature of the REDD+ program. This "depoliticization" is reflected in official REDD+ discourse, which effectively enables the Ghanaian state to divert responsibility for deforestation, maintain decision-making power, and enact contradictory national policies in sustainable forestry. At the same time, financial resources are also directed towards the State for the infeasible actualization of the forest carbon commodity, leaving critical concerns for local communities unaddressed in practice.

As a result, the Ghanaian government reaps financial gains without addressing the primary causes of deforestation under the veil of social inclusion. Civic environmentalism, largely social and environmental safeguards in this case, then, legitimize expanding State power in practice. Without ownership and management rights of land and trees and market reform, local communities then are further criminalized by the State as it expands. This power is cyclical in nature, which expands with each new, depoliticized fad in forest governance. At the same time, because REDD+ is highly localized in specific geographical areas and aspects of forestry, the Ghanaian government can still pursue carbon emitting and deforestation activities for more financial gain.

Interviewees discussed several ways that this cycle of international frameworks implemented at the state level could improve. First, these programs cannot ignore the politics of natural resource governments and only tout technical solutions. Future programs should prioritize consistent legal reforms for community ownership, management, and use rights a prerequisite. Additionally, market-based solutions should not be considered as they are expensive, limit participation, and only value one aspect of sustainable forestry management. Funding, also, should not go exclusively to State governments, but rather directly to local communities and CSOs on the ground in a lump sum. Finally, instead of new international frameworks every few years that are seen as momentary silver bullets, international frameworks should ensure that sustainable forestry national programs and policies are consistent, fair, and enforced.

Ferguson contends that state expansion, as an instrumental effect, is not intentional nor centralized [37]. The state does not "rationalize and centralize" power relations, rather it "grabs and loops around existing power relations to cinch them together like a knot" ([37], p. 274). Bureaucratic state power, then, is a mode of power that relies on state institutions but exceeds them. REDD+ in Ghana operates in a similar way, as depoliticizing discourse and governmentality squash political challenges to the program and create disjointed policies at the national level which establishes REDD+ as an unsustainable conservation fad. The fad, then, allows for the expansion of the state to the detriment of local communities and the forest.

Funding: This research received no external funding.

Institutional Review Board Statement: The study was conducted according to the guidelines of the Declaration of Helsinki, and approved by the Institutional Review Board (or Ethics Committee) of The Graduate Institute of International and Development Studies (January 2019).

Informed Consent Statement: Informed consent was obtained from all subjects involved in the study.

Acknowledgments: I would like to thank my interviewees in Ghana, who referred me with good wishes to other informants and shared openly with me, as well as my advisor Shaila Galvin, who was readily available for support and feedback.

Conflicts of Interest: The author declares no conflict of interest.

\section{References}

1. Newell, P.; Paterson, M. Climate Capitalism: Global Warming and the Transformation of the Global Economy; Cambridge University Press: Cambridge, UK, 2010.

2. Pirard, R. Market-based instruments for biodiversity and ecosystem services: A lexicon. Environ. Sci. Policy. 2012, 19, 59-68. [CrossRef]

3. Zhang, B. Market-based solutions: An appropriate approach to resolve environmental problems. Chin. J. Popul. Resour. Environ. 2013, 11, 87-91. [CrossRef] 
4. Wunder, S.; Brouwer, R.; Engel, S.; Ezzine-de-Blas, D.; Muradian, R.; Pascual, U.; Pinto, R. From principles to practice in paying for nature's services. Nat. Sustain. 2018, 1, 145-150. [CrossRef]

5. Arsel, M.; Büscher, B. Nature ${ }^{\mathrm{TM}}$ Inc.: Changes and Continuities in Neoliberal Conservation and Market-based Environmental Policy. Dev. Chang. 2012, 43, 53-78. [CrossRef]

6. McElwee, P. Payments for environmental services as neoliberal market-based forest conservation in Vietnam: Panacea or problem? Geoforum 2012, 43, 412-426. [CrossRef]

7. Adams, W. Sleeping with the enemy? Biodiversity conservation, corporations and the green economy. J. Political Ecol. 2017, 24, 243-257. [CrossRef]

8. Bakker, K. Neoliberalizing Nature? Market Environmentalism in Water Supply in England and Wales. Ann. Assoc. Am. Geogr. 2005, 95, 542-565. [CrossRef]

9. Bakker, K. The "Commons" Versus the "Commodity": Alter-globalization, Anti-privatization and the Human Right to Water in the Global South. Antipode 2007, 39, 430-455. [CrossRef]

10. OECD. Green Investment Banks: Scaling up Private Investment in Low-carbon, Climate-resilient Infrastructure, Green Finance and Investment; OECD Publishing: Paris, France, 2016. [CrossRef]

11. OECD. Mobilising Bond Markets for a Low-Carbon Transition, Green Finance and Investment; OECD Publishing: Paris, France, 2017. [CrossRef]

12. OECD. Making Blended Finance Work for the Sustainable Development Goals; OECD Publishing: Paris, France, 2018. [CrossRef]

13. OECD; The World Bank; UN Environment. Financing Climate Futures: Rethinking Infrastructure; OECD Publishing: Paris, France, 2018. [CrossRef]

14. UNFCCC. Key Decisions Relevant for Reducing Emissions from Deforestation and Forest Degradation in Developing Countries (REDD+): Decision Booklet REDD+; 2016; Available online: https://unfccc.int/files/land_use_and_climate_change/redd/application/pdf/ compilation_redd_decision_booklet_v1.1.pdf (accessed on 1 October 2021).

15. McAfee, K. The Contradictory Logic of Global Ecosystem Services Markets. Dev. Chang. 2012, 43, 105-131. [CrossRef]

16. McDermott, C.; Levin, K.; Cashore, B. Building the Forest-Climate Bandwagon: REDD+ and the Logic of Problem Amelioration. Glob. Environ. Politics 2011, 11, 85-103. [CrossRef]

17. Streck, C. Who Owns REDD+? Carbon Markets, Carbon Rights and Entitlements to REDD+ Finance. Forests 2020, 11, 959. [CrossRef]

18. Feindt, P.H.; Oels, A. Does discourse matter? Discourse analysis in environmental policy making. J. Environ. Policy Plan. 2005, 7, 161-173. [CrossRef]

19. Scheba, A.; Scheba, S. REDD+ as 'inclusive' neoliberal conservation: The case of Lindi, Tanzania. J. East. Afr. Stud. 2017, 11, 526-548. [CrossRef]

20. Allan, J.I.; Dauvergne, P. The Global South in Environmental Negotiations: The politics of coalitions in redd +. Third World Q. 2013, 34, 1307-1322. [CrossRef]

21. Rowe, E.W. Locating international REDD+ power relations: Debating forests and trees in international climate negotiations. Geoforum 2015, 66, 64-74. [CrossRef]

22. Di Gregorio, M.; Gallemore, C.T.; Brockhaus, M.; Fatorelli, L.; Muharrom, E. How institutions and beliefs affect environmental discourse: Evidence from an eight-country survey on REDD+. Glob. Environ. Chang. 2017, 45, 133-150. [CrossRef]

23. Nielsen, T.D. The role of discourses in governing forests to combat climate change. Int. Environ. Agreem. Polit Law Econ. 2013, 14, 265-280. [CrossRef]

24. Stephan, B. Bringing discourse to the market: The commodification of avoided deforestation. Environ. Politics 2012, 21, 621-639. [CrossRef]

25. Christen, D.R.; Espinosa, M.G.; Reumann, A.; Puri, J. Results based payments for REDD+ under the green climate fund: Lessons learned on social, environmental and governance safeguards. Forests 2020, 11, 1350. [CrossRef]

26. Bayrak, M.M.; Marafa, L.M. Ten Years of REDD+: A Critical Review of the Impact of REDD+ on Forest-Dependent Communities. Sustainability 2016, 8, 620. [CrossRef]

27. Hajjar, R.; Engbring, G.; Kornhauser, K. The impacts of REDD+ on the social-ecological resilience of community forests. Environ. Res. Lett. 2021, 16, 024001. [CrossRef]

28. Satyal, P. Civil society participation in REDD+ and FLEGT processes: Case study analysis from Cameroon, Ghana, Liberia and the Republic of Congo. For. Policy Econ. 2018, 97, 83-96. [CrossRef]

29. Ameyaw, L.K.; Ettl, G.J.; Leissle, K.; Anim-Kwapong, G.J. Cocoa and Climate Change: Insights from Smallholder Cocoa Producers in Ghana Regarding Challenges in Implementing Climate Change Mitigation Strategies. Forests 2018, 9, 742. [CrossRef]

30. Isyaku, U.; Arhin, A.A.; Asiyanbi, A.P. Framing justice in REDD+ governance: Centring transparency, equity and legitimacy in readiness implementation in West Africa. Environ. Conserv. 2017, 44, 212-220. [CrossRef]

31. Saeed, A.-R.; McDermott, C.; Boyd, E. Examining equity in Ghana's national REDD+ process. For. Policy Econ. 2018, 90, 48-58. [CrossRef]

32. Asiyanbi, A.; Arhin, A.A.; Isyaku, U. REDD+ in West Africa: Politics of Design and Implementation in Ghana and Nigeria. Forests 2017, 8, 78. [CrossRef]

33. Jaeger, H.-M. “Global Civil Society” and the Political Depoliticization of Global Governance. Int. Politics Sociol. 2007, 1, $257-277$. [CrossRef] 
34. Blaikie, P.; Brookfield, H. Land and Degradation and Society; Methuen \& Co Inc.: London, UK, 1987; p. 284.

35. Forsyth, T. Critical Political Ecology: The Politics of Environmental Science; Routledge: London, UK; New York, NY, USA, 2013.

36. Mouffe, C.; Laclau, E. Hegemony and Socialist Strategy: Towards a Radical Democratic Politics; Verso: New York, NY, USA, 1985.

37. Ferguson, J. The Anti-Politics Machine: "Development," Depoliticization, and Bureaucratic Power in Lesotho; Cambridge University Press: Cambridge, UK, 1990; in print.

38. Foucault, M. Truth and Power, an interview. Crit. Anthropol. 1979, 4, 131-137. [CrossRef]

39. Nasi, R.; Putz, F.E.; Pacheco, P.; Wunder, S.; Anta, S. Sustainable Forest Management and Carbon in Tropical Latin America: The Case for REDD+. Forests 2011, 2, 200-217. [CrossRef]

40. Ciplet, D.; Roberts, J.T. Climate change and the transition to neoliberal environmental governance. Glob. Environ. Chang. 2017, 46, 148-156. [CrossRef]

41. McCormick, S. The Brazilian Anti-Dam Movement. Organ. Environ. 2006, 19, 321-346. [CrossRef]

42. Dryzek, J.S. The Politics of the Earth: Environmental Discourses, 3rd ed.; Oxford University Press: Oxford, UK, 2013.

43. Bäckstrand, K.; Lövbrand, E. Planting Trees to Mitigate Climate Change: Contested Discourses of Ecological Modernization, Green Governmentality and Civic Environmentalism. Glob. Environ. Politics 2006, 6, 50-75. [CrossRef]

44. Mol, A.; Spaargaren, G.; Sonnenfeld, D. Ecological Modernization Theory: Where Do We Stand? Campus Verlag: Frankfurt, Germany, 2014; ISBN 9783593500614.

45. Coalition for Rainforest Alliance in Papua New Guinea, Conference May 2005. Available online: https:/ / wrm.org.uy/articles-fromthe-wrm-bulletin/section1/papua-new-guinea-rainforest-alliance-undermining-forest-conservation-efforts/ (accessed on 1 October 2021).

46. Ghana REDD+ Strategy, Republic of Ghana. 2016. Available online: https://www.oldwebsite.fcghana.org/userfiles/files/ REDD\%2B/Ghana\%20REDD\%2B\%20Strategy.pdf (accessed on 1 October 2021).

47. Hajer, M.A.; Fischer, F.; Forester, J. Discourse Coalitions and the Institutionalization of Practice. In The Argumentative Turn in Policy Analysis and Planning; Duke University Press: Durham, CA, USA, 1993; pp. 43-76. [CrossRef]

48. Participatory Self-Assessment and Synthesis of Ghana's REDD+ Readiness Process (R-Package), July 2016. Accra, Ghana. Available online: https:/ / www.forestcarbonpartnership.org/system/files/documents/Ghana\%20RPackage \%20Final\%20for\% 20posting\%20clean\%20doc.pdf (accessed on 12 February 2019).

49. Agbosu, L. Customary and Statutory Land Tenure, and Land Policy in Ghana; Institute of Statistical, Social \& Economic Research, University of Ghana: Legon, Ghana, 2007.

50. Concessions Act, Ghana Code. 1962. Available online: http://extwprlegs1.fao.org/docs/pdf/gha168936.pdf (accessed on 1 October 2021).

51. PAB Development Consultants. A Framework for Tree Tenure and Benefit Sharing Scheme in Ghana. 2016. Available online: https: //www.oldwebsite.fcghana.org/userfiles/files/NREG/Draft\%20Final\%20Report_30_05_16\%20.pdf (accessed on 19 February 2019).

52. Constitution, Ghana Code. 1992. Available online: https://www.constituteproject.org/constitution/Ghana_1996.pdf?lang=en (accessed on 12 June 2019).

53. Ghana Forest and Wildlife Policy, Ghana Code. 2012. Available online: http://extwprlegs1.fao.org/docs/pdf/gha144198.pdf (accessed on 1 October 2021).

54. UN-REDD Programme I How We Work. (n.d.). Available online: https:/ / www.un-redd.org/how-we-work (accessed on 13 June 2019).

55. Tortajada, C. Nongovernmental Organizations and Influence on Global Public Policy. Asia Pac. Policy Stud. 2016, 3, 266-274. [CrossRef]

56. West, P. Conservation Is Our Government Now: The Politics of Ecology in Papua New Guinea; Escobar, A., Rocheleau, D., Eds.; Duke University Press: Durham, NC, USA, 2006.

57. Ghana FCPF ER Program Advanced Draft BSP. 2018. Available online: https://www.forestcarbonpartnership.org/system/files/ documents/Ghana\%20FCPF\%20ER\%20Program\%20Advanced\%20Draft\%20BSP.pdf (accessed on 23 June 2019).

58. Seyller, C.; Desbureaux, S.; Ongolo, S.; Karsenty, A.; Simonet, G.; Faure, J.; Brimont, L. The 'virtual economy' of REDD+ projects: Does private certification of REDD+ projects ensure their environmental integrity? Int. For. Rev. 2016, 18, 231-246. [CrossRef]

59. Ghana ER Program GCFRP Benefit Sharing Plan. Available online: https://vdocument.in/advanced-draft-enefit-sharing-planghana-ocoa-forest-redd-ghana-er-program-gcfrp.html (accessed on 1 October 2021).

60. Corbera, E.; Brown, K.; Adger, W.N. The Equity and Legitimacy of Markets for Ecosystem Services. Dev. Chang. 2007, 38, 587-613. [CrossRef]

61. Ghana Cocoa Forest REDD+ Programme. Available online: https://www.forestcarbonpartnership.org/system/files/documents / GCFRP_Carbon\%20Fund_Final\%20Draft_April\%2022\%202017-formatted.pdf (accessed on 14 May 2019).

62. Lund, J.F.; Sungusia, E.; Mabele, M.B.; Scheba, A. Promising Change, Delivering Continuity: REDD+ as Conservation Fad. World Dev. 2017, 89, 124-139. [CrossRef] 